\title{
Distinguishing iron deficiency anaemia from thalassemia trait in clinical obstetric practice
}

\author{
Adam S Akers ${ }^{1 *}$, Denise Howard ${ }^{2}$ and Jason Ford ${ }^{3}$ \\ ${ }^{1}$ Department of Clinical Medicine, Weill Cornell Medicine - Qatar and Sidra Medical and Research Center, Qatar \\ ${ }^{2}$ Department of Clinical Obstetrics and Gynecology, Weill Cornell Medicine - Qatar and Sidra Medical and Research Center, Qatar \\ ${ }^{3}$ Department of Clinical Pathology and Laboratory Medicine, Weill Cornell Medicine - Qatar and Division of Hematopathology, Sidra Medical and Research \\ Center, Qatar
}

\begin{abstract}
Anaemia in pregnancy is common, occurring in approximately $38 \%$ of pregnancies. Iron deficiency anaemia (IDA) accounts for most cases (55\% - 70\%) depending on the population being studied. However, both alpha and beta thalassemia trait cause microcytic, hypochromic anaemia and are commonly misdiagnosed as IDA. Thalassemia trait (or minor) should be considered when there is a microcytic anaemia that is not improving with iron therapy or when anaemia predates the pregnancy, especially in a patient from a high risk ethnic group. Also, certain features on the complete blood count (CBC) indices can suggest thalassemia trait such as microcytosis out of proportion to the anaemia along with a raised RBC count. A diagnosis of beta thalassemia trait can be made by the detection of an elevated $\mathrm{Hb}$ A2. A diagnosis of alpha thalassemia trait can be made by demonstrating Hemoglobin $\mathrm{H}$ bodies on the peripheral blood smear using special stains. In some thalassemia patients with equivocal phenotypic results, genetic testing for specific thalassemia mutations may be required. Identification of women with thalassemia trait is important for genetic counselling as well as avoiding unnecessary iron replacement therapy.
\end{abstract}

\section{Introduction}

Mild anaemia, with a hemoglobin as low as $10 \mathrm{mg} / \mathrm{dl}$ is expected in normal pregnancy due to hemodilution. However, the incidence of anaemia due to iron deficiency in pregnancy is high, between $25 \%$ and $40 \%$ percent depending on the population studied $[1,2]$. Iron deficiency occurs when the body iron stores become depleted, as measured by a serum ferritin level below $12-15 \mathrm{ng} / \mathrm{ml}$ [3]. Iron deficiency anaemia (IDA) is defined as iron deficiency accompanied by low hemoglobin. The usual causes of iron deficiency in obstetrics are increased dietary requirements of pregnancy, inadequate supplementa-tion, and inadequate stores at the onset of pregnancy [4].

Dietary iron is most bioavailable as heme (ferrous) iron which is found in meat, poultry, and fish. Non-heme (ferric) iron is found in egg yolks, legumes, nuts, dried fruits, and whole grains. However, non-heme iron is poorly absorbed, and iron absorption in general is inhibited by several substances such as dietary calcium and polyphenols which are present in coffee and tea. In developed countries, a large proportion of women do not have adequate iron stores or sufficient ongoing dietary iron intake to prevent IDA [5], and this is even more pronounced in countries where a vegetarian diet and tea consumption are common such as in Southeast Asia [2].

Iron is an essential element for the developing fetus both for the formation of blood cells and iron containing enzymes in the central nervous system [6]. Iron deficiency in pregnant women increases the risk of mortality from bleeding [7] and sepsis [8] thus obstetricians tend to be vigilant about pre-scribing iron supplementation. However, under treatment and overtreatment of iron deficiency may be clinically problematic. Guidelines on the prophylaxis and supplementation of iron are not consistent, and excessive iron replacement has theoretical risks, such as the concern for increased oxidative stress [9], the generation of highly reactive non-transferrin bound iron [10], and the inhibition of iron on the absorption of other divalent metals [11]. Also, a significant number of individuals with Northern European heritage are heterozygous for hemochromatosis, and these women have a tendency towards iron overload and will not benefit from empiric iron prophylaxis.

In resource poor countries, generalized iron prophylaxis is recommended due to widespread iron deficiency. In these countries, a strategy of universal iron prophylaxis affords a better balance of risk and benefit in terms of preventing iron deficiency in pregnancy. The World Health Organization (WHO) recommends that $60 \mathrm{mg}$ of elemental iron be given for 6 months of pregnancy and 3 months postpartum when universal prophylaxis is indicated [12]. In resource rich countries, individualized iron prophylaxis is preferred in order to avoid unnecessary iron replacement, and iron stores can be checked using a serum ferritin in early pregnancy or preconception [13]. A ferritin level of $<30 \mathrm{ng} / \mathrm{ml}$ indicates inadequate iron stores and ferrous iron should be given at $60-80 \mathrm{mg}$ daily. A ferritin level of 30-70 ng/ $\mathrm{dl}$ indicates at risk for iron deficiency and ferrous iron should be given at $30-40 \mathrm{mg}$ daily beginning in the 10 th week to ensure adequate iron delivery throughout the pregnancy. When the ferritin is $>80$

Correspondence to: Adam S. Akers, MD FACP, Assistant Professor of Clinical Medicine, Weill Cornell Medicine- Qatar and Senior Attending Physician Internal Medicine, Sidra Medical and Research Center, Qatar, Tel +974-74793524; Email: aakers@sidra.org

Key words: anaemia, microcytosis, pregnancy, thalassemia

Received: November 02, 2017; Accepted: November 16, 2017; Published: November 18, 2017 
$\mathrm{ng} / \mathrm{dl}$ then there are adequate iron stores for pregnancy and no iron supplementation needs to be given [14].

Oral iron replacement should be given between meals to enhance absorption, and a response should be seen as an increase in hemoglobin level within two weeks [15]. If a patient's anaemia is multifactorial (for example, if iron deficiency occurs on a background of thalassemia or anaemia of chronic disease), the hemoglobin level will not accurately reflect the effectiveness of iron replacement. The serum ferritin or the ratio of serum transferrin receptor (sTfR) to serum ferritin can be used to follow the response to iron replacement in these cases [16].

Of all of the causes of non-iron deficient anaemias, thalassemia trait is the most common and difficult to distinguish from IDA since it causes a microcytic, hypochromic anaemia. This paper will review the characteristics of thalassemia trait, when to suspect it, how to distinguish it from IDA, and the clinical implications of the diagnosis.

\section{Genetics of alpha and beta thalassemia}

Normal red blood cells (RBCs) each contain approximately 300 million molecules of hemoglobin $(\mathrm{Hb})$. In adults there are three main types of hemoglobin molecule: $\mathrm{HbA}$, which on average represents around $96 \%$ of the hemoglobin; $\mathrm{HbA} 2$, which is approximately $3 \%$, and $\mathrm{HbF}$, which is approximately $1 \%$. Each $\mathrm{HbA}$ molecule consists of four globin chains, two alpha and two beta, each with an associated heme group that can reversibly bind one oxygen molecule. (HbA2 and $\mathrm{HbF}$ combine alpha globins with delta globins and gamma globins, respectively.) The globin components of $\mathrm{HbA}$ are proteins which are coded by the alpha and beta globin genes. There are two copies of the alpha gene on each chromosome 16 and one copy of the beta gene on each chromosome 11. Given that two copies of each chromosome are present, this means that each individual should have four copies of the alpha gene and two copies of the beta gene.

Mutations in the alpha or beta globin genes can cause abnormal variants of $\mathrm{HbA}$ (hemoglobinopathies, such as sickle cell disease) or a decrease in production of one of the respective globin chain types (thalassemia) [17]. Alpha thalassemia is usually caused by a deletion of one or more of the alpha globin genes, leading to a decrease in alpha chain production and a relative excess of beta chains. There are nondeletional forms of alpha thalassemia, which may be more severe than deletional forms, but these are less common. The excess beta chains form tetramers called Hemoglobin $\mathrm{H}$, or $\mathrm{HbH}$, within the $\mathrm{RBC}$, which precipitate on the inner $\mathrm{RBC}$ membrane and damage the cell leading to its premature destruction (i.e. hemolysis). In beta thalassemia, there is usually a point mutation in a beta globin promoter region, leading to a decrease in beta chain production and a relative excess of alpha chains. These ex-cess alpha chains also precipitate on the RBC's inner membrane surface, and lead to hemolysis and ineffective hematopoiesis. Depending on the number of genes affected and the type of mutation (e.g. deletional or nondeletional in alpha thalassemia), there is a spectrum of clinical phenotypes in both alpha and beta thalassemia from asymptomatic to various degrees of chronic hemolytic anaemia, splenomegaly, ineffective hematopoiesis, bone marrow expansion, skeletal deformities, and in the worst cases hydrops fetalis leading to intrauterine death [18].

Alpha thalassemia deletions may affect both alpha genes on the same chromosome (this double-deletion mutation is designated $\alpha^{0}$ ), or only one alpha gene on a chromosome $\left(\alpha^{+}\right)$[19]. Since there are two pairs of alpha genes, several combinations of defects are possible (heterozygote, double heterozygote, compound heterozygote, or homozygote), each with varying degrees of clinical severity (table 1). The heterozygous $\alpha^{+}$state, with one deleted alpha gene out of four, is known as the (silent) carrier state: this genotype is represented as aa/a-, indicating three normal alpha genes and one deleted gene. The alpha thalassemia carrier state is asymptomatic, and patients have a normal CBC. These patients are only detected through genetic testing of relatives of individuals who are more severely affected.

Alpha thalassemia trait is the condition of two missing alpha genes, either homozygous $\alpha^{+}$(a-/a-) or heterozygous $\alpha^{0}$ (aa /- -), and is characterized by a mild microcytic, hypochromic anaemia with no clinical symptoms.

When three of the four alpha genes are missing (a-/--) Hemoglobin $\mathrm{H}$ (alpha thalassemia minor) dis-ease is present: this is a clinically heterogeneous condition, and patients may have various degrees of chronic hemolysis, jaundice, splenomegaly, ineffective erythropoiesis, and occasional blood transfusion dependence. Both alpha thalassemia trait and Hemoglobin $\mathrm{H}$ disease should be apparent, at least on the $\mathrm{CBC}$, from the time of birth. All of the hemoglobin molecules in the neonate and the adult make use of the alpha globin chain, so its absence manifests early in development.

The deletion of all four alpha globin genes (called Hemoglobin Barts Hydrops Fetalis, with a genotype --/--) is incompatible with extra-uterine life since all forms of postnatal hemoglobin contain alpha chains ( $\mathrm{HbA}, \mathrm{HbA} 2$, and $\mathrm{HbF}$ ) and the complete absence of alpha chains makes normal oxygen transport impossible [20].

Table 1. Thalassemia Syndromes

\begin{tabular}{|c|c|c|c|}
\hline Thalassemia Syndrome & Genotype & Clinical Manifestations & Blood Cell Indices \\
\hline $\begin{array}{l}\text { Alpha Thalassemia Asymptomatic Carrier } \\
\text { State }\end{array}$ & $(\mathrm{aa} / \mathrm{a}-)$ & Asymptomatic & Normal \\
\hline \multirow{3}{*}{ Alpha or Beta Thalassemia Trait } & $(\mathrm{aa} /--)$ or $(\mathrm{a}-/ \mathrm{a}-)$ & \multirow{3}{*}{ Asymptomatic } & $\mathrm{Hb}$ : Normal to moderate anaemia \\
\hline & $\left(\mathrm{b}^{+} / \mathrm{b}\right)$ or $\left(\mathrm{b}^{0} / \mathrm{b}\right)$ & & $\mathrm{MCV}<80 \mathrm{fl} ; \mathrm{MCH}<27 \mathrm{pg}$ \\
\hline & & & Elevated or normal RBC count \\
\hline \multirow{3}{*}{$\begin{array}{l}\text { Hemoglobin } \mathrm{H} \text { disease (Alpha thalassemia } \\
\text { minor) }\end{array}$} & \multirow{3}{*}{$(\mathrm{a}-/--)$} & \multirow{3}{*}{$\begin{array}{l}\text { Spectrum of clinical disease- chronic } \\
\text { hemolysis, splenomegaly, jaundice. Variable } \\
\text { transfusion dependence. }\end{array}$} & Moderate to severe anaemia \\
\hline & & & $\mathrm{MCV}<80 \mathrm{fl} ; \mathrm{MCH}<27 \mathrm{pg}$ \\
\hline & & & Elevated or normal RBC count. \\
\hline \multirow{3}{*}{ Beta Thalassemia Intermedia } & \multirow{3}{*}{$(\mathrm{b}+/ \mathrm{b}+)$ or $(\mathrm{b}+/ \mathrm{b} 0)$} & \multirow{3}{*}{$\begin{array}{l}\text { Spectrum of clinical disease- chronic } \\
\text { hemolysis, splenomegaly, jaundice. Not } \\
\text { transfusion dependent, although occasional } \\
\text { transfusions may be required }\end{array}$} & Moderate to severe anaemia \\
\hline & & & $\mathrm{MCV}<80 \mathrm{fl} ; \mathrm{MCH}<27 \mathrm{pg}$ \\
\hline & & & Elevated or normal RBC count \\
\hline \multirow{2}{*}{ Beta Thalassemia Major } & \multirow{2}{*}{ (b0/b0) } & \multirow{2}{*}{$\begin{array}{l}\text { Transfusion dependent hemolytic anaemia, } \\
\text { ineffective hematopoesis, iron overload }\end{array}$} & $\mathrm{Hb}<6 \mathrm{~g} / \mathrm{l}$ \\
\hline & & & Marked microcytosis and hypochromia \\
\hline Hemoglobin Barts Hydrops Fetalis & $(--/--)$ & Intrauterine death & \\
\hline
\end{tabular}


Nondeletional forms of alpha thalassemia may be more severe than simple deletions. The most com-monly encountered nondeletional alpha thalassemia is called Constant Spring $\left(\alpha^{\mathrm{CS}}\right)$, which is usually found in patients with Asian ethnicities-even though it is named after the index patient's adopted hometown in Jamaica. In $\alpha^{\mathrm{CS}}$, a mutation in the stop codon of one of the alpha genes leads to an elongated alpha chain. This abnormal alpha chain is unstable and interferes with the production of the remaining normal alpha chains, causing a more severe phenotype [21]. The combination of a double deletion $\left(\alpha^{0}\right.$, aa /- -) with a nondeletional alpha thalassemia mutation can cause a more severe form of Hemoglobin $\mathrm{H}$ disease. Hemoglobin H Constant Spring (Hb HCS, rendered genotypically as aCSa/--) is clinically more severe than deletional Hemoglobin $\mathrm{H}$ disease (a-/--).

Beta thalassemia mutations are most commonly of the nondeletional type with point mutations in the promoter region of the beta globin gene often found. Mutations which result in a mild or moderate reduction in beta chain production are referred to as $\beta+$, and those causing a complete absence of beta chain production from the affected gene are $\beta 0$.

Beta thalassemia trait results when a $\beta+$ or $\beta 0$ mutation is paired with a normal beta globin gene (designated $\beta / \beta+$ or $\beta / \beta 0$ ): this is generally asymptomatic and shows a mild microcytic hypochromic anaemia on the $\mathrm{CBC}$, similar to alpha thalassemia trait.

When there is a combination of $\beta+$ and $\beta 0$ mutations (e.g. $\beta+/ \beta+$, $\beta 0 / \beta 0$, or $\beta+/ \beta 0)$, the clinical phenotype is designated as either beta thalassemia intermedia or beta thalassemia major. In intermedia, there is typically a moderate microcytic anaemia and occasional transfusion dependence, similar to Hemoglobin $\mathrm{H}$ disease. In major, patients typically have a severe microcytic anaemia and lifelong transfusion depend-ence. The distinction between beta thalassemia intermedia and major is a clinical one, relying on the degree of clinical symptoms and the degree of transfusion dependence. As a rule it is not possible to predict, simply by reviewing the $\mathrm{CBC}$ or the genotype, whether a patient should be classed as inter-media or major. These conditions show a spectrum of disease including chronic hemolysis, ineffective erythropoiesis, splenomegaly, jaundice, and iron overload due to transfusion dependence (Table 1). In the most severe untreated cases of beta thalassemia major, patients may show skeletal abnormalities owing to the massive proliferation of erythropoiesis in the marrow cavity. The response to erythropoietin is so brisk, and the resulting erythropoiesis so ineffective, that the erythropoietic population within the marrow space expands into the cortical bone, leading to severe bony deformity.

Unlike in alpha thalassemia, where the reduction in alpha chains leaves the beta chains with nothing to bind to apart from other beta chains, there are two other "beta like" globin chains: gamma and delta. These normally pair with alpha chains to form $\mathrm{HbF}$ (two alpha chains and two gamma chains) and HbA2 (two alphas and two deltas), albeit in relatively small proportions in postnatal life. The production of these chains is increased in patients with beta thalassemia, because the excess alpha chains will compensate by pairing more frequently with gamma and delta chains. The laboratory diagnosis of beta thalassemia relies on this increase in $\mathrm{HbA2}$; the increase in $\mathrm{HbF}$ is less consistent and diagnostically less reliable. Because of the normally high levels of $\mathrm{HbF}$ in early postnatal life, beta thalassemia does not become clinically apparent until a newborn is several months old. After six months of age, when most of the hemoglobin has switched from fetal $\mathrm{HbF}(\alpha 2$ $\gamma 2$ ) to adult $\mathrm{HbA}(\alpha 2 \beta 2)$, the relative lack of beta chains will manifest in microcytic anaemia and an elevated HbA2 ( $\alpha 2 \delta 2)$ [22]. There is a wide clinical spectrum of disease in adults, due to a variety of factors including differences in each person's ability to clear the excess alpha chains, ability to produce fetal hemoglobin, and degree of impaired produc-tion of the beta chain. In some cases the genotype-phenotype correlation is so complex that it cannot be explained by known genetic and physiologic mechanisms [23].

It is not uncommon for an individual to be co-heterozygous with alpha and beta thalassemia, or com-pound heterozygous for thalassemia and a hemoglobin variant due to the high frequency of these mu-tations in some populations. Co-heterozygosity for alpha and beta thalassemia tends to attenuate the severity of the syndrome since it partially restores the balance of alpha and beta chain production (alt-hough this is not the case in every patient) [24]. Some hemoglobinopathy/thalassemia combinations are not particularly significant (such as alpha thalassemia plus sickle cell trait), while others may be quite serious (e.g. $\beta 0$ / HbS, $\beta 0$ / $\mathrm{HbE}$, and $\beta 0 / \mathrm{Hb}$ Lepore). [25].

\section{Epidemiology}

The thalassemia mutations are endemic in Southeast Asia, the Indian subcontinent, the Mediterranean, the Middle East, and Africa due to the protective effect of thalassemia trait on acquiring severe falciparum malaria. This is thought to be a result of the elevated number and smaller size of red blood cells in thalassemia trait, which (among other theorized mechanisms) may interfere with the malaria parasite's ability to cause severe hemolysis [26].

The $\alpha^{+}$allele is ubiquitous in all areas where thalassemia is seen, and is present in approximately $20 \%$ of the world population [27]. It is considered to be clinically insignificant by itself since the offspring of two parents who carry the $\alpha^{+}$allele will in the worst case express the double heterozygous thalassemia trait $(\alpha-/ \alpha-)$, which is generally clinically asymptomatic. The $\alpha^{0}$ allele is highly genetically significant, since the compound heterozygous state $\alpha^{+} \alpha^{0}$ leads to $\mathrm{HbH}$ disease, and homozygous $a^{00}$ leads to Hemoglobin Barts Hydrops Fetalis. The most common $\alpha^{0}$ types are (- - SEA) which is found in Southeast Asia and South China; (- - MED) found in Greece, Turkey, Cyprus, Iran, Arab populations, and Sardinia; (- - FIL) found in the Philippines; and (- THAI) found in Thailand. The $\alpha^{0}$ allele is not commonly found in India or Africa [28]. If $\alpha^{0}$ is combined with one of the non-deletional alpha thalassemia mutant hemoglobins (such as Constant Spring), this combination produces a more severe form of Hemoglobin $\mathrm{H}$ disease [29].

The distinction between mild and potentially severe $\beta^{+}$lesions in beta thalassemia is less clear because of the large number of identified mutations (over 300) and the genotype/ phenotype dissociation. The $\beta^{0}$ allele is most commonly seen in Southeast Asia but is also seen in India, the Middle East (Iran, Iraq, and Syria), the Mediterranean, and North Africa (Tunisia, Algeria, and Morocco). The areas which have the highest number of children with transfusion dependent $\beta$-thalassemia are Southeast Asia, Eastern Mediterranean, Western Pacific, and North Africa [27].

The presence of these mutations in Central and South America, arise from the African or Mediterranean ancestry of the population studied [30]. Centuries of increased migration and intermarriage have resulted in a rising prevalence of thalassemia in North America, Western Europe, and Australia [31]. A survey by the North America Thalassemia Research Network in 2004 showed an increasing incidence of thalassemia births in North America reflecting a diverse ethnic population [32]. Antenatal screening is now offered routinely in the UK and in many other parts of the world [33]. 


\section{Clinical suspicion}

Thalassemia in a pregnant woman should be suspected when there is a microcytic $(\mathrm{MCV}<80 \mathrm{fL})$ and/or hypochromic $(\mathrm{MCH}<27 \mathrm{pg})$ anaemia and any of the following: failure to respond to iron therapy, anaemia which predates the pregnancy and is not consistent with IDA, normal or elevated red blood cell count (RBC), or member of a high risk ethnic group. Different numbers and calculations based on the CBC have been carefully evaluated to see if they are useful in predicting iron deficiency or thalassemia [34,35]. Medical students are frequently taught to rely on the RDW (classically the RDW is said to be high in iron deficiency and normal in thalassemia), however this has poor predictability. The two best measures or calculations from the $\mathrm{CBC}$ are the Red Blood Cell count alone (RBC) and the Mentzer Index (MCV/RBC). An RBC above $5 \times 1012 / 1$ is often seen in thalassemia, while a count $<5$ is more typical of iron deficiency. As demonstrated by Demir (2002) and Beyan (2007), using RBC count in this way has a sensitivity and specificity of nearly $90 \%$, and classifies approximately $90 \%$ of patients correctly. A Mentzer index $<13$ suggests thalassemia trait as opposed to IDA, with a sensitivity of approximately $90 \%-98 \%$ depending on the population being studied $[36,37]$. These approaches are merely rules of thumb as no hematologic indices will perfectly distinguish thalassemia trait from IDA [38]. When thalassemia trait is suspected the next step is to order specialized testing.

\section{Laboratory diagnosis}

The diagnosis of beta thalassemia is generally made using High Performance Liquid Chromatography (HPLC) or Capillary Zone Electrophoresis (CZE), while alpha thalassemia can be diagnosed using a phenotypic method (a special stain of the peripheral blood smear) or a genotypic method which identifies the common mutations $[39,40]$. In some labs, much of this testing may be collectively described as "hemoglobin electrophoresis", although strictly speaking routine hemoglobin electrophoresis is not precise enough as a stand-alone test to diagnose thalassemia.

In alpha thalassemia excess beta chains precipitate into betatetramer molecules called Hemoglobin $\mathrm{H}(\mathrm{HbH})$. If a peripheral smear is stained with brilliant cresyl blue or other supravital stains (called " $\mathrm{H}$ body staining"), $\mathrm{HbH}$ is visible microscopically as an intraerythrocytic precipitate. The sensitivity of $\mathrm{H}$ body staining is quite variable, depending on the genotype. The $\mathrm{H}$ body test is rarely positive in patients with alpha thalassemia carrier status (aa/a-). In patients with a double deletion in trans (a-/a-), the sensitivity is approximately $40 \%$, compared to approximately $90 \%$ in patients with a double deletion in cis (aa/--) [41]. In cases of uncomplicated Hemoglobin H disease (a-/-), the test is almost always positive, with $\mathrm{H}$ bodies visible in the majority of RBCs. In practice, the $\mathrm{H}$ body test is useful in detecting (and ruling out) Hemoglobin $\mathrm{H}$ disease, and it is useful when it is positive in cases of alpha thalassemia trait, however a negative $\mathrm{H}$ body result does not rule out alpha thalassemia trait.

In beta thalassemia trait, the deficiency of beta globin chains leads alpha chains to pair instead with gamma and delta chains. This leads to an increase in $\mathrm{HbA} 2$ (which contains delta globins) and frequently also $\mathrm{HbF}$ (which contains gamma). The rise in $\mathrm{HbA} 2$ is reliable enough to diagnose beta thalassemia trait and in those with risk factors, an $\mathrm{HbA} 2$ above $3.5 \%$ is enough to diagnose beta thalassemia trait [42].

Using an elevated $\mathrm{HbA} 2$ to diagnose beta thalassemia trait is not perfect: some patients with beta thalassemia trait will have a normal $\mathrm{Hb}$ A2 (e.g. due to the suppression of HbA2 caused by iron deficiency), and some patients without beta thalassemia trait may see a falsely elevated HbA2 level (e.g. in hyperthyroidism, megaloblastic anaemia, sickle cell trait, or antiretroviral therapy) [43]. Given the suppressive effect of iron deficiency on HbA2 levels, serum ferritin should always be checked at the time of evaluation for thalassemia trait [44].

These HPLC and CZE methods are also useful in diagnosing patients with beta thalassemia intermedia or major. These patients show an elevation of $\mathrm{HbA} 2$, a severe elevations of $\mathrm{HbF}$ and a deficiency of HbA which can be totally absent in severe cases. HPLC and CZE may also identify the most common non-deletional form of alpha thalassemia (i.e. Hb Constant Spring), as well as the non-thalassemic hemoglobinopathies such as HbS [45-48].

Genetic testing has a role in thalassemia diagnosis, but its importance is quite different in alpha and beta thalassemia. Beta thalassemia trait can, in practice, almost always be diagnosed by HPLC. Only rarely is genetic testing required (e.g. if the delta globin gene and the beta globin gene are both affected, which would produce a beta thalassemia syndrome with a normal $\mathrm{HbA2}$ ). In some of these patients, sequencing of the beta globin gene may be diagnostic; other patients may benefit from allele specific oligonucleotide hybridization (ASO) [49] or reverse dot blot analysis (RDB) [50]. In alpha thalassemia trait, genetic testing may be required more frequently, due to the insensitivity of the main phenotypic testing method (i.e. H body staining). PCR methods may be necessary to target the most common deletions as well as non-deletional mutations [51]. Alpha globin gene sequencing may be important in some patients if PCR does not detect a mutation [52]. Whether genetic testing is required a discussion be-tween the clinician and the laboratory is advised. Genetic testing is most beneficial when used to pro-vide genetic counselling.

In areas with a high rate of thalassemia or mixed multiethnic populations, it may be appropriate and cost effective to proceed straight to ferritin and specialized thalassemia testing in all women with microcytosis. This was demonstrated in a pilot study in North London where $45 \%$ of women with multi-ethnic heritage were microcytic, and over half of those were diagnosed with alpha thalassemia trait [53].

\section{Clinical implications of identifying thalassemia trait}

Diagnosing thalassemia trait in a pregnant woman is of clinical benefit to her and potentially significant genetic benefit for her family. The detection of thalassemia trait may provide an explanation for a microcytic anaemia which will, in concert with a normal serum ferritin, rule out iron deficiency and allow the patient to reduce iron supplementation. The genetic benefit occurs if the woman's partner carries a thalassemia mutation. If they both carry beta thalassemia mutations, their children will be at risk for beta thalassemia major, which carries with it significant lifelong morbidity. Parents with alpha thalassemia mutations may have children with Hemoglobin $\mathrm{H}$ disease or Hemoglobin Barts Hydrops Fetalis. The diagnosis of thalassemia trait in a pregnant woman identifies a potentially at risk pregnancy.

The knowledge of the potential for an offspring with severe thalassemia can allow for early diagnosis with amniocentesis or chorionic villus sampling, genetic counselling and family planning. Genetic counselling of couples at risk for babies with thalassemia syndromes can be complicated as the genotype may not clearly predict the phenotype. In addition, intrauterine and postnatal therapies for thalassemia disease have advanced tremendously over the past few decades. Intrauterine transfusion, improved chelation therapy, new gene therapies, and bone marrow transplantation may be viable 
treatments [54]. Genetic counsellors need to be well versed in the current treatment options and local availability, so they can provide couples with the appropriate information to assist them in making a difficult decision [55].

For practitioners located in high risk areas, there may be programs in place for premarital, preconception, prenatal, or newborn screening. A targeted campaign in North Cyprus beginning in 1980 has been successful in virtually eliminating severe thalassemia births [56]. Other programs in the Middle East have had mixed success. Expanded carrier screening panels are now available for a large number of autosomal recessive genetic conditions [57]. However, in Western countries with mixed ethnic groups it may be more difficult to show utility in universal screening.

Patients with thalassemia trait and replete iron stores (ferritin > $70 \mathrm{ng} / \mathrm{mL}$ ) should not receive iron supplementation. Although these patients are not transfusion dependent, they may still develop iron overload later in life, which can lead to pulmonary hypertension and thrombosis [58]. Although the goal in treating iron deficiency in pregnancy is to raise the hemoglobin to $10 \mathrm{mg} / \mathrm{dl}$ or above, this will not be possible in many women with thalassemia trait. The ferritin level should be used to measure iron status, and the risks of iron deficiency in pregnancy must be balanced with the risks of unnecessary iron therapy. Signs of iron deficient erythropoiesis begin at a serum ferritin level of $25-40 \mathrm{mcg} / \mathrm{l}$ [59]. Therefore, it is reasonable when screening for iron deficiency in these patients to use a conservative value such as $40-50 \mathrm{mcg} / \mathrm{l}$ of serum ferritin as a goal for iron replacement since there will be ongoing iron requirements in pregnancy. Reflexively referring patients for intravenous iron when their hemoglobin levels are not rising with oral iron replacement subjects them to the potential of future iron overload, unnecessary cost, and inconvenience.

\section{Conclusion}

Both IDA and thalassemia trait can cause microcytic, hypochromic anaemia. Thalassemia trait is common in ethnic groups from Southeast Asia, the Indian subcontinent, the Mediterranean, Middle East, and Africa. Since IDA is common in pregnancy, the diagnosis of thalassemia trait is often overlooked or not considered in women with microcytic anaemia. Correctly identifying women with thalassemia trait has important implications for genetic counselling and avoiding unnecessary iron therapy.

\section{Authorship and contributorship}

All authors contributed equally the writing and editing of this manuscript.

\section{Acknowledgements}

None

\section{Funding information}

None

\section{Competing interests}

The authors declare that they have no competing interests.

\section{References}

1. Stevens GA, Finucane MM, De-Regil LM, Paciorek CJ, Flaxman SR et al. (2013) Global, regional, and national trends in haemoglobin concentration and prevalence of total and severe anaemia in children and pregnant and non-pregnant women for 19952011: a systematic analysis of population- representative data. Lancet Glob Health, 1: e16-25. [Crossref]
2. Benoist B, McLean E, Egll I, Cogswell M (2008) Worldwide prevalence of anaemia 1993-2005: WHO global database on anaemia. World Health Organization, Geneva, Switzerland.

3. Daru J, Allotey J, Peña-Rosas JP, Khan KS (2017) Serum ferritin thresholds for the diagnosis of iron deficiency in pregnancy: a systematic review. Transfusion Med, 27 167-174. [Crossref]

4. Scientific Advisory Committee on Nutrition. Iron and Health Report, 2011. London Public Health England.

5. Milman N, Byg KE, Ovesen L (2000) Iron status in Danes 1994: II: prevalence of iron deficiency and iron overload in 1319 Danish women aged 40-70 years. Influence of blood donation, alcohol intake and iron supplementation. Ann Hematol, 79: 612-621. [Crossref]

6. Grantham-McGregor S, Ani C (2001) A review of studies on the effect of iron deficiency on cognitive development in children. $J$ Nutr 131: 649S-666S. [Crossref]

7. Wilkinson $\mathrm{H}$ and on behalf of the Trustees and Medical Advisers (2011) Saving Mothers' Lives. Reviewing maternal deaths to make motherhood safer: 2006-2008. $B J O G, 118:$ 1402-1403. [Crossref]

8. Bamber JH, Kinsella SM (2015) MBRRACE-UK - the new home for the Confidential Enquiries into Maternal Deaths - reports for the first time. Anaesthesia, 70: 5-9. [Crossref]

9. Viteri EV, Casanueva E, Tolentino MC, D 'iaz-France SJ, Erazo AB (2012) Antenatal iron supplements consumed daily produce oxidative stress in contrast to weekly supplementation in Mexican non-anemic women. Reprod Toxicol, 34: 125-132. [Crossref]

10. Schumann K, Kroll S, Romero-Abal ME, Georgiou NA, Marz JM et al. (2012) Impact of oral iron challenges on circulating non-transferrin-bound iron in healthy Guatemalan males. Ann Nutr Metab, 60: 98-107. [Crossref]

11. Olivares M, Pizarro F, Ruz M, de Romaña DL (2012) Acute inhibition of iron bioavailability by zinc: studies in humans. Biometals 25: 657-664. [Crossref]

12. Stoltzfus R, Dreyfuss M (1998) Guidelines for the use of iron supplements to prevent and treat iron deficiency anaemia, The International Nutritional Anaemia Consultative Group, (INACG/WHO/UNICEF). Washington, DC, USA: LISI Press.

13. Milman, N (2012) Oral Iron Prophylaxis in Pregnancy: Not Too Little and Not Too Much! J Pregnancy 2012:514345. [Crossref]

14. Becker W, Lyhne N, Pederson AN, Aro A, Fogelholm M et al. (2004) Nordic Nutrition Recommendations 2004 - integrating nutrition and physical activity. Scandinavian Journal of Nutrition. 48:178-187.

15. Okam MM, Koch TA, Tran MH (2016) Iron Deficiency anaemia Treatment Response To Oral Iron Therapy: A Pooled Analysis Of Five Randomized Controlled Trials. Haematologica, 101, e6-e7. [Crossref]

16. Lin XM, Tian W, Ma L, Long Z, Zhang J, et al. (2008) The responses of serum transferrin receptors to iron supplements in subjects with iron-deficiency erythropoiesis and iron-deficiency anaemia. Br J Nutr, 99: 416-420. [Crossref]

17. Shang X, Xu X (2017) Update in the genetics of thalassemia: What clinicians need to know. Best Pract Res Clin Obstet Gynaecol, 39: 3-15. [Crossref]

18. Singer ST (2009) Variable Clinical Phenotypes of a-Thalassemia Syndromes ScientificWorldJournal, 9:615-625. [Crossref]

19. Origa R, Moi P, Galanello R (2005) Alpha-thalassemia. In: Adam MP, Ardinger HH, Pagon RA, Wallace SE, Bean LJH, Mefford HC, Stephens K, Amemiya A, Ledbetter N, editors. GeneReviews ${ }^{\circledR}$ [Internet]. Seattle (WA): University of Washington, Seattle; 1993-2017.

20. Galanello R, Cao A (2011) Gene test review. Alpha-thalassemia. Genet Med 13: 83-88 [Crossref]

21. Schrier SL, Bunyaratvej A, Khuhapinant A, Fucharoen S, Aljurf M, et al., 1997. The Unusual Pathobiology of Hemoglobin Constant Spring Red Blood Cells. Blood, 89: 1762-1769. [Crossref]

22. Thein SL (2013) The molecular basis of $\hat{\mathrm{I}}^{2}$-thalassemia. Cold Spring Harb Perspect Med 3: a011700. [Crossref]

23. Swee LT (2013) Genetic association studies in B- hemoglobinopathies. Hematology Am Soc Hematol Educ Program, 2013:354-61.

24. Melis MA, Pirastu M, Galanello R, Furbetta M, Tuveri T, et al. (1983) Phenotypic effect of heterozygous alpha and beta 0-thalassemia interaction. Blood, 62: 226-229. [Crossref] 
25. Petrou M Haemoglobinopathy Genetics User Handbook. Available from: https://www. uclh.nhs.uk/OurServices/

26. Fowkes FJ, Allen SJ, Allen A, Alpers MP, Weatherall DJ, et al. (2008) Increased Microerythrocyte Count in Homozygous a+-Thalassaemia Contributes to Protection against Severe Malarial Anaemia. PLoS Med 5: e56. [Crossref]

27. Modell B, Darlisona M (2008) Global epidemiology of haemoglobin disorders and derived service indicators. Bulletin of the World Health Organization, 86:.480-487.

28. Li CK (2017) New trend in the epidemiology of thalassaemia. Best Pract Res Clin Obstet Gynaecol. 39: 16-26. [Crossref]

29. Jomoui W, Fucharoen G, Sanchaisuriya K, Nguyen VH, Fucharoen S (2015) Hemoglobin Constant Spring among Southeast Asian Populations: Haplotypic Heterogeneities and Phylogenetic Analysis. PLoS One 10: e0145230. [Crossref]

30. Wagner SC, de Castro SM, Gonzalez TP, Santin AP, Filippon L. et al. (2010) Prevalence of common a-thalassemia determinants in south Brazil: Importance for the diagnosis of microcytic anaemia. Genet Mol Biol.. 33: 641-645. [Crossref]

31. Vichinsky EP (2005) Changing patterns of thalassemia worldwide. Ann N Y Acad Sci 1054: 18-24. [Crossref]

32. Vichinsky EP, MacKlin EA, Waye JS, Lorey F, Olivieri NF (2005) Changes in the epidemiology of thalassemia in North America: a new minority disease. Pediatrics 116 e818-825. [Crossref]

33. Sickle cell and thalassaemia screening: programme overview. 2013.

34. Demir A, Yarali N, Fisgin T, Duru F, Kara A (2002) Most reliable indices in differentiation between thalassemia trait and iron deficiency anaemia. Pediatr Int. 44: 612-616. [Crossref]

35. Beyan C, Kaptan K, Ifran A (2007) Predictive value of discrimination indices in differential diagnosis of iron deficiency anaemia and beta-thalassemia trait. Eur $J$ Haematol, 78: 524-526. [Crossref]

36. Ghafouri M, Motan SL, Sharifi SH, Hosseini GL, Atar CZ (2006) Comparison of cell counter indices in differentiation of beta thalassemia minor from iron deficiency anaemia. The Scientific Journal of Iranian Blood Transfusion Organization, 2:385-389.

37. Vehapoglu, A, Ozgurhan G, Demir AD, Usuner S, Nursoy MA et al. (2014) Hematological Indices for Differential Diagnosis of Beta Thalassemia Trait and Iron Deficiency anaemia. Anemia, 2014:576738 [Crossref]

38. Rosatelli C, Leoni GB, Tuveri T, Scalas, MT, Mosca A et al. (1992) Heterozygous beta-thalassemia: relationship between the hematological phenotype and the type of beta-thalassemia mutation. Am J Hematol, 39(1), e4. [Crossref]

39. Ryan K, Bain BJ, Worthington D, James J, Plews D et al. (2010) Significant haemoglobinopathies: guidelines for screening and diagnosis. $\mathrm{Br}$ J Haematol, 149: e49. [Crossref]

40. Langlois S, Ford JC, Chitayat D (2008) Carrier screening for thalassemia and hemoglobinopathies in Canada. J Obstet Gynaecol Can, 30: 950-959. [Crossref]

41. Skogerboe KJ, West SF, Smith C, Terashita ST, LeCrone CN, Detter JC, et al., 1992. Screening for alpha-thalassemia. Correlation of hemoglobin $\mathrm{H}$ inclusion bodies with DNA-determined genotype. Arch Pathol Lab Med, 116: 1012-1018. [Crossref]

42. Weatherall, D, Clegg JB (2001) The Thalassaemia Syndromes. 4th ed. Oxford: Blackwell Science.
43. Mosca A, Paleari R, Ivaldi G, Galanello R, Giordano PC. (2009) The role of haemoglobin A2 testing in the diagnosis of thalassaemias and related hae-moglobinopathies. $J$ Clin Pathol., 62: 13-17. [Crossref]

44. Wasi P, Disthasongchan P, Na-Nakorn S (1968) The effect of iron deficiency on the levels of hemoglobins A2 and E. J Lab Clin Med 71: 85-91. [Crossref]

45. Clarke GM1, Higgins TN (2000) Laboratory investigation of hemoglobinopathies and thalassemias: review and update. Clin Chem 46: 1284-1290. [Crossref]

46. Fucharoen S, Winichagoon P, Wisedpanichkij R, Sae-Ngow B, Sriphanich R, et al. (1998) Prenatal and postnatal diagnoses of thalassemias and hemoglobinopathies by HPLC. Clin Chem 44: 740-748. [Crossref]

47. Higgins T, Mack M, Khajuria A (2009) Comparison of two methods for the quantification and identification of hemoglobin variants. Clin Biochem 42: 701-705. [Crossref]

48. Liao C, Zhou JY, Xie XM, Li J, Li R, et al. (2010) Detection of Hb Constant Spring by a capillary electrophoresis method. Hemoglobin, 34: 175-178. [Crossref]

49. Clark BE, Thein SL (2004) Molecular diagnosis of haemoglobin disorders. Clin Lab Haematol, 26:159-176.

50. Saiki RK, Walsh PS, Levenson CH, Erlich HA (1989) Genetic analysis of amplified DNA with immobilized sequence-specific oligonucleotide probes. Proc Natl Acad Sci USA, 86: 6230-6234. [Crossref]

51. Galanello R, Sollaino C, Paglietti E, Barella S, Perra C, et al. (1998) alpha-thalassemia carrier identification by DNA analysis in the screening for thalassemia. Am. J. Hematol, 59: 273-278. [Crossref]

52. Fallah MS, Mahdian R, Aleyasin SA, Jamali S, Hayat-Nosaeid M, et al., 2010. Development of a quantitative real-time PCR assay for detection of unknown a-globin gene deletions. Blood Cells Mol Dis, 45: 58-64. [Crossref]

53. Wonke B, Modell M, Marlow T, Khan M, Modell B (2007) Microcytosis, iron deficiency and thalassaemia in a multi-ethnic community: a pilot study. Scand J Clin Lab Invest., 67: 87-96. [Crossref]

54. Mansilla-Soto J, Riviere I, Boulad F, Sadelain M (2016) Cell and Gene Therapy for the Beta-Thalassemias: Advances and Prospects. Hum Gene Ther 27: 295-304. [Crossref]

55. Dhamcharee V, Romyanan O, Ninlagarn T (2001) Genetic counseling for thalassemia in Thailand: problems and solutions. Southeast Asian J Trop Med Public Health., 32: 413-418. [Crossref]

56. Bozkurt G (2007) Results from the north cyprus thalassemia prevention program Hemoglobin 31: 257-264. [Crossref]

57. Haque IS, Lazarin GA, Kang HP, Evans EA, Goldberg JD, et al., 2016. Modeled fetal risk of genetic diseases identified by expanded carrier screening. JAMA, 316: 734-742. [Crossref]

58. Vichinsky, E. (2016) Non-transfusion-dependent thalassemia and thalassemia intermedia: epidemiology, complications and management. Curr Med Res Opin, 32: 191-204. [Crossref]

59. Hallberg L, Bengtsson C, Lapidus L, Lindstedt G, Lundberg PA et al. (1993) Screening for iron deficiency: an analysis based on bone-marrow examinations and serum ferritin determinations in a population sample of women. Br J Haematol, 85: 787-798. [Crossref]

Copyright: (C2017 Akers AS. This is an open-access article distributed under the terms of the Creative Commons Attribution License, which permits unrestricted use, distribution, and reproduction in any medium, provided the original author and source are credited. 